\title{
A combined focused industry and company size investigation of the internationalization- performance relationship: The case of small and medium-sized enterprises (SMEs) within the Swedish wood manufacturing industry
}

Mojtaba Hosseini, Staffan Brege and Tomas Nord

The self-archived postprint version of this journal article is available at Linköping University Institutional Repository (DiVA):

http:/ / urn.kb.se/ resolve?urn=urn:nbn:se:liu:diva- 153691

N.B.: When citing this work, cite the original publication.

Hosseini, M., Brege, S., Nord, T., (2018), A combined focused industry and company size investigation of the internationalization-performance relationship: The case of small and medium-sized enterprises (SMEs) within the Swedish wood manufacturing industry, Forest Policy and Economics, 97, 110-121. https:// doi.org/ 10.1016/j.forpol.2018.09.013

Original publication available at:

https:// doi.org/ 10.1016/j.forpol.2018.09.013

Copyright: Elsevier

http://www.elsevier.com/

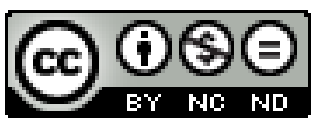




\title{
A combined focused industry and company size investigation of the internationalization-performance relationship: The case of small and medium-sized enterprises (SMEs) within the Swedish wood manufacturing industry
}

\begin{abstract}
The current literature has failed to deliver a coherent explanation of the internationalizationperformance (I-P) relationship. The empirical findings are quite confusing and even contradictory. Researchers have found positive, negative, U-shaped, inverted U-shaped, S-shaped, and inverted Sshaped relationships between degree of internationalization and performance. Based on plausible theoretical explanations such as networking effects, cost and benefit mechanisms and minimum efficient scale (MES), the recommendation for further research is to change focus - from an overall level to a more detailed country-industry and company size contextual level. The underlying assumption is that more specific contextual aspects are paramount to the existence and shape of the I-P relationship. Building on the resource-based view and the S-shape theory of internationalization, this paper aims at such an empirically focused investigation of SMEs within the Swedish wood manufacturing industry. A repeated cross-sectional survey study using hierarchical regression analysis has revealed a linear negative relationship between internationalization and performance. Given that wood manufacturing is a low-tech industry, not highly automated and with a low level of MES, the results are expected. The size of the Swedish market is big enough to amortize the initial investments of establishing a small wood manufacturing business, and the costs associated with internationalization diminish overall performance. In addition, the follow-up tests of ANCOVA (analysis of covariance) and piecewise regression revealed a non-linear relationship between (1) internationalization and performance for highly internationalized firms in 2001, (2) internationalization and growth for low internationalized companies in 2001, and (3) internationalization and performance for highly internationalized groups in the pooled dataset. Considering the costs and benefits associated with international activities, the non-linear effects of internationalization on performance or growth is plausible.
\end{abstract}

Keywords: Internationalization, performance, wood manufacturing industry, and S-shape theory.

\section{Introduction}

A quick look at the forest sector uncovers the increasing importance of internationalization in the industry, especially in recent years. Foreign direct investment (FDI) (Laaksonen-Craig, 2004) and the global export value (Zhang et al., 2014) have rapidly increased in the forest and wood manufacturing industry, and make internationalization a necessity in forest economics. In their study of the economic impacts of trade in the forest sector, Buongiorno et al. (2017) found international trade to be an important research area in the industry, one which substantially affects the global welfare of the sector. Considering internationalization as a widespread strategy for growth and performance, studying its consequences at corporate level has become a seminal issue, and a large number of research outcomes has also led to a number of meta-analysis studies being published (e.g., Bausch and Krist, 2007; Marano et al., 2016). Unfortunately, this is not true in the case of the forest sector. Despite the obvious lack of internationalization research from an organizational perspective in the sector and the recent emphasis on examining internationalization from a strategic management research point of view (Zhang et al., 
2014), little effort has been devoted to the subject.

The dominant liberal capitalistic view is that increased international trade is positive for GNP growth and for society at large. That presumption is easily transferred to be "the truth" for companies as well, and a large amount of research in international strategy and international marketing more or less explicitly builds upon that assumption (Contractor, 2007). However, this view quickly becomes more complicated and called into question when looking at the results of empirical studies. Despite all the endeavors, the current findings show mixed results regarding the empirically determined shape of the internationalization-performance (I-P) relationship, and a common theoretical understanding is far from being reached. The current inconclusive empirical evidence shows that research has yet to understand this complexity (Wiersema and Bowen, 2011).

The existing literature on the subject suggests a range of different causes for this inconsistency, such as the failure to pay proper regard to the moderating effects of other variables (Grant, 1987; Kirca et al., 2011; Marano et al., 2016), theoretical shortcomings, or even methodological and measurement problems (Contractor, 2007; Hennart, 2007; Sullivan, 1994). Research shows that internationalization is accompanied by essential benefits and costs which can produce positive or negative performance consequences. Economies of scale, international arbitrage, organizational learning, location-based advantages, and international opportunities are frequently mentioned as the positive effects of internationalization. At the same time, the rising costs resulting from the complexity of internationalization dynamics when expanding business activities beyond national borders have been considered as a negative effect (Hennart, 2007). There is no clear consensus on how the costs and benefits of internationalization interact to affect firm performance and growth. Until now, the most reasonable explanation in this regard seems to be the S-shape theory (Contractor, 2007).

The massive number of empirical studies shows there is no universal I-P relationship. Therefore, new research on the subject should not aim at generalization at the highest overall level covering all possible options (Bausch and Krist, 2007). Instead, we need to develop finer-grained models and start a bottom-up process with the design of studies with a limited focus on specific companies (e.g., SMEs or large companies) in a single industry and in a homogeneous country (Elango and Sethi, 2007). In international business, a homogeneous context is defined as an environment in which the psychic distance is low. Psychic distance is the perceived difference between two culturally separated contexts or groups of people regardless of physical time and space (Johanson and Vahlne, 1977). In line with this recommendation, this study has limited its focus to Swedish SMEs in the wood manufacturing industry (ranging from wooden components and low-value-added joinery to high-value wooden products such as windows, doors, kitchen/bath interiors and prefabricated floor/roof and volume elements for detached and multi-story houses, and also including furniture).

The aim of the study is not to formulate a general rule about the I-P relationship; instead, it is to understand the relationship and its shape and direction among the SMEs within the Swedish wood manufacturing industry. The wood manufacturing industry has a total revenue for 2012 of 87 billion SEK, with 33,000 people employed (Nord and Brege, 2014). The wood manufacturing industry can be looked upon as low-tech in $R \& D$, with a low degree of automatization in production and with low levels of minimum efficient scale (MES) (Nord and Brege, 2014). MES is the level of output at which the internal economies of scale have been entirely exploited, so the long run average cost is minimized, and the operator achieves constant returns to scale. In other words, companies rely on economies of scale to reduce their average cost in the long term. A given level of the production output that delivers 
the lowest average cost is called MES. Sweden, located in the north of Europe, is also a unique setting because of its small home market of nearly 10 million inhabitants.

Besides an industry focus, our study also has a second focus on small and medium-sized enterprises (SMEs). One reason for focusing on SMEs is because the I-P relationship is widely explored among multinational large companies, but comparatively little effort has been made to understand the relationship in reference to SMEs (Chiao et al., 2006; Lu and Beamish, 2001, 2006). SMEs are not smaller versions of large companies; thus, the results of large-firm studies cannot be automatically applied to them (Ruigrok et al., 2007). They have their own specific style of strategic management and they are substantially different from large companies in their process and policy of internationalization (Dana et al., 1999; Majocchi and Zucchella, 2003). Because of their limited financial base, small geographical scope and domestic focus, entering international markets is a more critical decision for SMEs (Lu and Beamish, 2006).

The remainder of the paper is structured as follows: The theoretical underpinning of the I-P relationship is discussed in the next section. It is accompanied by a review of the empirical studies in general, and among wood manufacturing SMEs in particular. Following that, the methodology of the research is presented, which is followed by the results and discussion, and rounded off with the conclusions. To summarize the applicable conclusions and build a foundation for future research, the managerial implications, research limitations and suggestions for further studies are discussed at the end.

\section{Theoretical frame of reference}

\subsection{Theoretical perspectives}

I-P studies have mainly applied different mainstream theories such as finance theory of portfolio diversification, the resource-based view, transaction cost economies, and organizational learning theory to understand how internationalization affects company performance (Hennart, 2007; Tsao and Chen, 2010). However, again there is no consensus about the most suitable frameworks to decipher the relationship. In his seminal discussion, Hennart (2007) has critically evaluated the current arguments in the field and concluded that there is no theoretical basis for expecting a systematic I-P connection. However, he suggested transaction cost economies as an applicable rationale to explain the performance consequences of internationalization. The basic notion of this theory is that markets and firms are interchangeable institutions to arrange exchange between firms in general, and that this could also be applied to the analysis of firms from different countries. The efficiency of markets or firms as coordinators of exchange is different and depends on the context. While markets rely on the price mechanisms, firms establish an exchange through hierarchy (Hennart, 2000). One prediction, in line with transaction cost theory, is that companies will invest in foreign markets that are close in cultural aspects; hence, they avoid the rising cost of governance caused by cultural distance while, at the same time, enjoying the benefits of investing in different countries (Hennart, 2007).

However, transaction cost economies give a rather limited perspective on internationalization (Contractor, 2007). The resource-based view complements the theoretical foundation by focusing on resources that create a sustainable competitive advantage by being unique, valuable, and very difficult to imitate (Barney, 1991). These resources can be successfully transferred to international markets (Chiao et al., 2006), and internationalization can be a powerful strategy for leveraging resources and further improving sustainable competitive advantage (Bausch and 
Krist, 2007).

A new theoretical perspective which has better potential to explain the dynamic of the I-P relationship and reconcile the existing conflicts among empirical findings is the promulgated 3 -stage theory (Contractor, 2007). According to this rationale, firms go through a sequential 3-stage path when increasing their international activities. In each stage, there are incremental benefits as well as incremental costs for adding a new foreign country to the international portfolio. In the first (early internationalization) and the last (excessive internationalization) stages, the costs of adding a new nation outweigh the benefits and lead to a negative performance consequence. In the middle stage of the internationalization path, adding a new country to the portfolio leads to a positive performance consequence. In stage two, companies have acquired enough knowledge and experience to overcome the liabilities of foreignness. Also, the number of countries in the second stage has not exceeded the optimum threshold of handling and managing costs (Contractor, 2007).

Summing up on the use of theoretical frameworks explaining the I-P relationship, there is no single theory with the potential to cover all the aspects. Therefore, researchers are recommended (de Chernatony et al., 2005; Jack and Raturi, 2006; Ma and Norwich, 2007) to triangulate existing theories with respect to the company situations and the specific environmental contexts. Theory triangulation consists of using more than one theory to interpret a phenomenon (Jack and Raturi, 2006). Therefore, when a research question is approached from more than one theoretical perspective, it is called theory triangulation (de Chernatony et al., 2005).

\subsection{Empirical studies of the I-P relationship}

Fortunately, besides theoretical frames of references, a massive body of empirical research exists on the I-P relationship. Empirical results, generally, have been very inconclusive about the existence and shape of the I-P connection, yielding support for no relationship (Majocchi and Zucchella, 2003; McDougall and Oviatt, 1996), negative linear relationships (Lu and Beamish, 2006; Wan and Hoskisson, 2003), positive linear relationships (Banalieva and Sarathy, 2011; Bausch and Krist, 2007; Elango, 2006; Elango and Sethi, 2007; Marano et al., 2016; Tsao and Chen, 2010), inverted U-shaped relationships (Banalieva and Sarathy, 2011; Chen and Hsu, 2010; Chiao et al., 2006; Elango, 2006; Pattnaik and Elango, 2009), U-shaped relationships (Assaf et al., 2012; Lu and Beamish, 2001; Ruigrok and Wagner, 2003; Thomas, 2006; Zhang and Toppinen, 2011), and S-shaped relationships (Contractor et al., 2003; Lu and Beamish, 2004; Outreville, 2010; Ruigrok et al., 2007). Despite the vast number of empirical studies in general, the lack of this kind of study in the forest industry is not easily explained. Until Zhang \& Toppinen's (2011) quantitative analysis of the I-P relationship in the global forest industry, there was no such research in the forest or wood manufacturing industry. Zhang \& Toppinen's study also suffered from some serious shortcomings, such as having a very small sample size. In addition, they examined the I-P relationship using a cross-sectional analysis, while the longitudinal study is recommended as the proper way to evaluate the relationship (Zhang and Toppinen, 2011). Surprisingly, we could not find any other specific quantitative analysis on the I-P relationship after Zhang \& Toppinen (2011). This shows the necessity of performing a fresh longitudinal quantitative analysis on the I-P relationship in the forest industry with a large sample size.

To combine the different results of existing studies and achieve a common conclusion regarding the existence and shape of such a relationship, a number of meta-analysis studies have been performed. In a very recent meta-analysis study, Marano et al. (2016) found a positive I-P relationship. But, as they clearly noted, the overall effect of the 
size of the relationship is very small and varies greatly across different countries. In fact, they showed that the performance consequences of internationalization could be both positive and negative, depending on the firms' home countries. For example, while the connection is negative among Mexican firms, there are companies around the globe which can benefit from internationalization (e.g., in South Korea and Greece) or their performance is entirely independent of that (e.g., in the Netherlands and Spain) (Marano et al., 2016). These findings indicate that considering the moderating effect of the home country is, in a way, more important than trying to understand the general pattern of the I-P relationship. Without controlling the effect of the home country, the I-P studies "are likely to be underspecified both theoretically and empirically" (Marano et al., 2016, p. 1077). Firms in smaller countries are forced to internationalize earlier (Bausch and Krist, 2007; Elango and Sethi, 2007) because they cannot reach MES by focusing only on their relatively restricted domestic markets. As a result, they become more experienced in handling unfamiliar foreign markets, cultural differences, international regulations, and trade laws (Bausch and Krist, 2007), which helps them to act more successfully in the international markets. This is generally known as the county of origin effect (COE) (Elango and Sethi, 2007).

Recently, the I-P relationship has received increased empirical attention because of new studies that apply more advanced models. While past studies mostly relied on linear (e.g., Grant, 1987) or, in some cases, quadratic models (e.g., Gomes and Ramaswamy, 1999), new studies assumed an S-shaped relationship between internationalization and performance based on a sigmoid model (e.g., Contractor, 2007; Contractor et al., 2003). This model has immediately found its place in the literature as a "benchmark model" (Glaum and Oesterle, 2007). Proponents of the linear connections rely on the benefits of the internationalization, such as risk reduction and economies of scale, to explain a positive I-P relationship. They also put forward the rising costs of managing and handling activities in describing the negative performance consequences of internationalization. Advocates of a more complex nonlinear relationship criticize the linear explanation for taking a too simplified and static view of the IP relationship (e.g., Contractor et al., 2003; Lu and Beamish, 2004). They propose a more dynamic view, and combine both the advantages and the disadvantages of internationalization to infer a U-shape or inverted U-shape of the connection. In their rationale, some companies are at the optimum point of internationalization in which they earn the maximum benefits, while there are others which still have not reached the optimum point or have already passed that point. These later positions show lower performance consequences because of a less than optimal interplay between the costs and benefits of internationalization. As a rough indication, this point has been placed somewhere between 40 and 70 percent of foreign sales to total sales (Ruigrok et al., 2007).

All in all, the shape of the nonlinear relationship is determined by the situation in which the companies are performing when the research has been executed. In the early stage of foreign expansion, fundamental entrance cost is generated from the high "liability of foreignness and newness" as well as the high level of learning costs and insufficient economies of scale (Contractor et al., 2003). By learning how to handle these initial costs through adjusting organizational structures, processes and systems, companies start to receive more income while keeping costs under control (Contractor et al., 2003). In such a situation, increased international expansion will augment firm performance. Unfortunately, firms do not experience the infinite increasing performance consequences of internationalization, because at some point they face an "internationalization threshold". From this threshold onwards, increased organizational and environmental complexity makes the costs larger than the subsequent benefits. Proponents of both the linear and the nonlinear explanations of the U-shape and inverted U-shape use transaction cost economies and the resource-based view as theoretical underpinnings. The S-shaped relationship 
takes a longer view and follows the rationale of the sigmoid 3-stage theory to reconcile the contradictions between the U-shape and inverted U-shape explanations.

\subsection{Control variables for more coherent results}

Grant (1987) classified research on the I-P connection into comparative studies that examine whether international companies outperform their domestic counterparts, and control research that investigates the connection by removing the disturbing effects of other variables such as firm size, industry, country of origin and so on. Identifying and controlling the most related disturbing variables is a pivotal prerequisite, and ignoring this may be the "root cause" behind the existing contradictions among empirical findings. The type of firms, their country of origin and their sectoral characteristics have been suggested as variables that can powerfully influence the shape and the direction of an I-P relationship (Contractor, 2007). Unfortunately, past studies have not introduced enough control variables when hypothesizing and testing the connection (Contractor, 2007; Hennart, 2007). Some of the disturbing effects that are more straightforward, such as the research density, could be controlled simply through statistical analysis. However, variables such as firm size, industry, and the country of origin need more in-depth discussion.

The S-shape theory provides a practical explanation about how firm size, industry, and country of origin can influence internationalization. It uses a dynamic interaction of the benefits and cost of internationalization to predict the I-P connection. According to this theory, companies experience a performance downturn at the beginning of internationalization because they suffer from the "liabilities of newness". At the moderate level of internationalization, they enjoy increasing performance levels and again they experience another performance turndown at the high degree of internationalization (Chiao et al., 2006; Contractor, 2007; Ruigrok et al., 2007). Researchers in the 1970s disregarded the costs associated with internationalization, and thus hypothesized a positive relationship by emphasizing the benefits. This changed in the 1980s and 1990s, when researchers acknowledged that internationalization can be subject to risk and failure (Bausch and Krist, 2007). Today, researchers relying on the S-shape theory are suggesting a different relationship between internationalization and performance, depending on the internal and external factors.

The first factor to be considered when discussing the I-P connection is the size of the companies in the sample. SMEs are not just smaller replicates of their larger counterparts. Rather, they have their own special characteristics, which enable them to plan and perform entirely differently. In their internationalization, for instance, they encounter peculiar challenges that are commonly discussed as the "internationalization barriers of SMEs" in the literature. These barriers are the factors that may decrease the SMEs' capacity to act successfully in international markets. They internally originated from the lack of resources or were imposed externally by the business environment (Leonidou, 2004; Leonidou et al., 2007). Networking has been suggested as a plausible strategy to overcome these barriers (Coviello and McAuley, 1999; Yeoh, 2004). Consequently, the internationalization process takes place differently for SMEs: it needs more coordination and takes place through different entry modes, and decreases the SMEs' control over their international operations because of the need to be aligned with the common objectives of business networks.

The effect of industry on the I-P connection is a long-standing discussion in the literature, and the number of studies that found an essential impact for industry on this connection is quite high. For instance, in their meta- 
analysis study, Marano et al. (2016) concluded that the I-P relationship is stronger for companies in the chemical industry compared to other industries such as banking, finance, and insurance. To explain the effect of industry, Hennart's (2007) argument of the strength of scale economies seems coherent. He argued that "firms in different industries are likely to have different cost curves, with different levels of MES [minimum efficient scale]"(p. 435). Companies with a higher initial investment, both in tangible and intangible assets, are more likely to experience a stronger positive connection between their early internationalization and performance because the domestic market is usually not big enough to efficiently utilize the capacity of their initial investment. These differences in level of MES across industries led Hennart to conclude that “... studies examining the relationship between international diversification and performance should be performed at a much lower level of aggregation, for example at a detailed industry level" (p. 446).

The impact of industry on the I-P relationship is even stronger when firm size has also been considered. Because of their limited resources, SMEs are less likely to enter the industries with high fixed costs unless they can find a network to compensate for their financial limitations. Therefore, in a low-fixed-cost industry in which firms could reach the minimum efficient scale from their domestic markets, it would be plausible to conclude that the number of companies that are entering international markets are few and the I-P connection is negative. This is essentially true for SMEs that mainly rely on cooperative networks to compensate for their financial limitations. The alignment costs imposed by the network and the liability of newness associated with entering a new market outweigh the expected benefits and decrease the overall performance.

The MES arguments clearly point at another factor that needs to be regarded when discussing the effect of internationalization on performance: the size of the domestic market, which determines whether or not a company in a given industry can reach MES (Hennart, 2007). If the domestic market is not big enough to reach the MES, then it is expected that a positive relationship can be found between internationalization and performance in that market. This is because if companies remain in their small local market, they cannot reach the MES at which the costs are counterbalanced by the benefits. These arguments corroborate well with the current empirical studies (e.g., Glaum and Oesterle, 2007; Marano et al., 2016). In a multi-country study of internationalization, Elango and Sethi (2007) showed a positive linear relationship between internationalization and performance in countries with small home markets, but an inverted U-shaped relationship in countries with relatively big economies. The conjunct effect of both industry and the size of the domestic market is an essential discussion, and one which is neglected to a large extent. As mentioned before, different industries have different MES points depending on their initial required investments; thus, it is reasonable to say that the I-P relationship is stronger and positive for industries in which the MES could not be reached through the local market. In summary, company size, industry, and the size of the domestic market all interact to determine the shape and direction of I-P relationship. Smaller companies tend to enter low fixed-cost industries in which reaching the MES needs a smaller market size. In this situation companies prefer to focus more on their domestic market, thus becoming quite familiar with that market but acquiring no international experience. Having no or little experience to handle the challenges of international markets increases the cost of internationalization which may lead to a negative performance consequence.

Our empirical focus on SMEs within the Swedish manufacturing industry is a timely response to Hennart's recommendation for studying the I-P relationship at a much lower level of aggregation and trying to handle the problems with different control variables. We have chosen (1) a small and open market, Sweden; (2) an industry 
that is low-tech and with a low level of MES, wood manufacturing; and (3) SMEs, as type of company which dominates this industry. With these classifications, the following hypothesis will be deducted from our theoretical discussion:

Hypothesis: The degree of internationalization negatively influences the performance of SMEs within the Swedish wood manufacturing industry.

\section{Methodology}

\subsection{Sample selection and data sources}

To resolve the current disagreement in the literature, I-P studies are recommended to limit their focus to a selected industry in a homogeneous country. While some studies utilized dummy variables to control the effect of industry, there are other studies which have chosen a specific industry in which to perform their research. Applying dummy variables, especially in I-P studies, which are highly affected by the industry, could lead to decreasing statistical power, an indistinct level of analysis, and adding extra complexity to longitudinal studies in which the dummy variables are also used to separate the time points. In their detailed review of industry effect, Sharp et al. (2013) stated that using dummy variables to control the industry effect could quickly decrease the ratio of observation to the variable models. Compensating for this low ratio, researchers need to collect more data which is costly and time consuming. Consequently, adding more dummy variables may cause data insufficiency which consequently decreases the statistical power. Another challenge with using dummy variables to control the industry is their effect on making the level of analysis indistinct. While some researchers define the dummy industries at the four-digit SIC level (e.g., McWilliams and Siegel, 2000), there are other studies which used the two-digit SIC level (e.g., Lu and Beamish, 2001), or even the sector level of manufacturing versus service (e.g., Lane et al., 2001).

These challenges forced some researchers to avoid using dummy variables, and instead report their findings for each industry separately (e.g., Chiao et al., 2006). Reporting the findings for each industry separately does not seem to be an applicable solution because it also suffers from all the above-mentioned challenges. Single industry study, multiple industry controls, and quasi industry controls have been introduced as other alternatives to control the industry effect (Dess et al., 1990; Sharp et al., 2013). All these strategies have their own advantages and disadvantages (see Sharp et al., 2013), and a researcher should select the most appropriate one based on the purpose and the question which is intended to be answered. Following Hennart's recommendation to study the I-P relationship at a lower level of aggregation, the purpose of this paper is to examine the relationship between internationalization and performance in the Swedish wood manufacturing industry. We have selected the wood manufacturing industry to obviate the above-mentioned problems of dummy industries and avoid the generalizability trap, which lies behind the current disagreement among the I-P studies. Single industry studies have been generally accepted as an applicable way of controlling the industry effect in strategic management literature. Sharp et al. (2013) found that "nearly half of the most impactful empirical articles published in strategy over the previous decade were conducted in a single-industry setting" (Kuratko and Audretsch, 2013, p. 48). This is especially useful for performance studies (any study which uses performance as either a dependent or an independent variable) in which the high or low level of performance is defined quite arbitrarily (Sharp et al., 2013). Consistent with other studies on internationalization and entrepreneurship, this study - a repeated cross-sectional study built upon two surveys - employs the SME definition provided by the European Union: stand-alone 
businesses with fewer than 250 employees and annual earnings of less than 47 million euros.

The process of deciding upon total populations and executing the surveys was the same. First, a list of all active companies in the Swedish wood manufacturing industry was received from the industry organizations Swedish Wood and the Swedish Federation of Wood and Furniture Industry. These lists were also compared to the companies listed in the official SIC statistics. Questionnaires were sent to a total of 632 companies in 2001 and 650 companies in 2014. To increase the probability of getting a high response rate, a letter from the CEOs of those industry organizations was attached to the questionnaires. In addition, two follow-up reminders were sent to the respondents by email. In total, 401 questionnaires were collected: 247 in 2001 and 154 in 2014. Seven companies from both 2001 and 2014 were removed because they did not meet the conditions of being SMEs. In total, the overall response rate was $31.3 \%: 39.1 \%$ for 2001 and $23.7 \%$ for 2014 .

\subsection{Variables and measures}

Internationalization is an extremely complex phenomenon, and its effect on performance is very likely to appear over time. Therefore, studying the phenomenon over time is considered to be the proper approach to investigate the I-P relationship (Glaum and Oesterle, 2007). In order to incorporate the time-effect relationship into our research, we combined two independent surveys with data from the Swedish wood manufacturing industry, one from 2001 and one from 2014. We estimate that the 13 years of time-lag is large enough to reveal the time-effect relationship in the research.

\subsubsection{Performance: dependent variable}

Casting a quick look at the literature highlights the fact that there is no universal measurement of performance. Marano et al. (2016) introduced four different measures of firm-level performance based on the findings of Hitt et al. (2006): (1) accounting-based measures, (2) market-based measures, (3) sales growth, and (4) survey-based measures. Furthermore, they found out that the measures of firm performance are positively but not highly correlated. Although the number of studies that use accounting measures is high, this kind of measurement has serious drawbacks (Outreville, 2010). This could be even worse in the case of SMEs, where accounting measures, at least in some countries, are less reliable than in larger companies.

Despite all the drawbacks of accounting measures, we have still decided to rely on them to study the I-P relationship because access to the archival accounting measures such as return on capital (ROC) is easier, they are more reliable in countries with rigorous tax assessment such as Sweden, and those measurements still play a crucial role for SMEs in establishing and developing external networks with financial intermediaries, suppliers, and public institutions. In addition, the accounting measurements of performance are regarded as acceptable in the literature (Chiao et al., 2006), and a large body of research on the I-P connection has already applied accounting-based measures such as ROC, return on equity (ROE), return on assets (ROA) and so on (Tsao and Chen, 2010). Therefore, employing this type of measurement could be more helpful when comparing with the aggregate conclusions of related studies. Furthermore, a meta-analysis study performed by Bausch and Krist (2007) revealed no difference in the relationship between internationalization and different measures of firm performance. In our study, we will also look for the relationship between internationalization and growth to see if internationalization affects both growth and profitability in the same direction. 
Firm performance can be determined using different accounting-based measures such as ROA, ROC, and ROE. In their study of companies' performance, Nollet et al. (2016) showed that these three measurements of firm performance differ in terms of volatility. While ROE was the most volatile, ROC displayed the least volatility. ROC grasps economic success at aggregate level and shows how successful companies are at earning income from capital. It has a positive correlation with market-based performance (Nollet et al., 2016), which reflects the firms' market operating efficiency (Banalieva and Sarathy, 2011). Consequently, we employ ROC to measure company performance.

Another aspect which conveys a deeper explanation is performance growth. Business studies define growth as the changes in total sales (Filatotchev and Piesse, 2009; Kylaheiko et al., 2011), turnover (Hessels and Parker, 2013), employment (Wynarczyk and Watson, 2005), or ROA (Tushman and Rosenkopf, 1996). While most researchers measure growth objectively, there are other studies which focus on subjective growth of companies (Davis and Harveston, 2000). We define growth as the changes in ROC from the time at which the data were collected to one year later.

\subsubsection{Internationalization: independent variable}

A long-standing criticism directed against I-P studies is that they often experience inconsistencies between theory and the operationalization of internationalization (Hennart, 2007). While there are some studies which apply international "scope" (e.g., number of countries) to measure internationalization, most empirical studies measure a firm's internationalization in terms of its "scale" (e.g., the foreign sales to total sales, foreign employees to total employees, or foreign assets to total assets ratios). In reality, these two measurements consider two different facets of internationalization: scale shows the strategic concern that a company attributes to serving international markets, while scope relies on heterogeneity and counts the number of international markets.

International business studies consider international SMEs as predominantly exporting companies in the sense that major assets are still kept in the domestic market, such as development and production. In other words, SMEs mainly rely on the entry modes with low initial investment such as exporting rather than the heavy investment choices like foreign direct investment (FDI) or opening a plant in a foreign market. For this kind of company, the scale of export is deemed to be more relevant for I-P analysis than the scope. Thus, the independent variable of this study is defined as the international sales ratio, which is consequently operationalized as the ratio of foreign sales to total sales. This is reasonable, firstly because our sample is dominated by SMEs, companies which are characterized by their limited access to sufficient resources in pursuing foreign direct investments (Chiao et al., 2006). Secondly, international scale is the most relevant measurement to helping reconcile previous research because it is by far the most common operationalization used (Fernhaber, 2013). And thirdly, previous studies have found that the different measurements of internationalization correlate highly with each other (Ruigrok et al., 2007), and the differences in measuring the internationalization do not lead to significantly different results in the I-P relationship (Bausch and Krist, 2007).

\subsubsection{Control variables}

Performance has many antecedents and could be simultaneously influenced by different factors. Size (Chiao et al., 2006; Glaum and Oesterle, 2007; Outreville, 2010; Ruigrok et al., 2007; Tsao and Chen, 2010), industry (Contractor, 2007; Hennart, 2007), country of origin (Elango, 2006; Hennart, 2007) and R\&D intensity (Chiao et 
al., 2006; Elango and Sethi, 2007) have been discussed as important factors in I-P analysis. Thus, we chose to control for their effects. In our study, the effects of industry and the country of origin were removed by limiting our sample to Swedish wood manufacturing industry companies. Research on a single industry serves well as an efficient design to control for industry effects (Elango and Sethi, 2007). The disturbance effect of size has been contained by limiting the sample to SMEs and by adding the size to the hierarchical regression analysis. Hierarchical regression is a useful technique when the predictors' variables are correlated with each other or to analyze the pure effect of predictors after controlling for disturbing variables (Pedhazur, 1997). Research intensity, however, has been controlled through hierarchical regression analysis. Firm size is measured as the number of employees, and research intensity as the physical and monetary resources a company spends on designing and developing new products.

\section{Results and discussion}

To test the hypothesis and answer the research question, we applied both cross-sectional and panel design analysis with OLS estimation for all three shapes (linear, quadratic, and cubic). At first, the following cross-sectional OLS regression, including degree of internationalization (DOI) and performance, was estimated for each time point:

$$
\text { Performance }=\mathrm{B}_{0 \mathrm{t}}+\mathrm{B}_{1 \mathrm{t}}(\mathrm{DOI})+\mathrm{B}_{2 \mathrm{t}}(\mathrm{DOI})^{2}+\mathrm{B}_{3 \mathrm{t}}(\mathrm{DOI})^{3}+\mathrm{e}
$$

Then, a pooled regression model was estimated by adding time $(\mathrm{t})$ as a dummy variable $(2001=0 ; 2014=1)$ :

$$
\text { Performance } \left.=\mathrm{B}_{0}+\mathrm{B}_{1}(\mathrm{t})+\mathrm{B}_{2}(\mathrm{DOI})+\mathrm{B}_{3}(\mathrm{DOI})^{2}+\mathrm{B}_{4}(\mathrm{DOI})^{3}+\mathrm{B}_{5}((\mathrm{DOI}) \mathrm{t})\right)+\mathrm{B}_{6}\left((\mathrm{DOI})^{2} \mathrm{t}\right)+\mathrm{B}_{7}\left((\mathrm{DOI})^{3} \mathrm{t}\right)+\mathrm{e} \text {. }
$$

This method allows researchers to examine variation over time simultaneously with cross-sectional variation among units. The hierarchical regression technique was used to perform the cross-sectional analysis by adding size and research intensity at the first step, DOI at the second step, DOI square at the third step, and DOI cubic term at the last step. A pooled regression with fixed effect estimation has also been applied to examine the shape and sign of the I-P relationship over time. Missing cases were estimated using the expectation-maximization (EM) technique. EM is an iterative two-step technique of missing value estimation in which the expected likelihood is estimated using the current parameters (expectation) and then the new parameters are calculated to maximize the likelihood found in the expectation step (Maximization). This technique delivers a reliable estimation for the regression type of analysis (Gold and Bentler, 2000; Little, 1988; Zhang et al., 2016).

The correlation analysis (Table 1) revealed that most coefficients among independent variables are not significant; hence, the probability of multicollinearity is very low. To be sure, however, we estimated a variance inflation factor (VIF) to double-check the problem of multicollinearity. VIF is a popular measure for estimating the amount of multicollinearity in a multiple regression analysis. It quantifies the degree of correlation between one predictor and all other variables in a model. All the VIF values were below 2, demonstrating that the issue of multicollinearity is not a major concern driving our results (Bowerman and O'Connell, 1990).

To check the presence of homoscedasticity in the data, both Breusch and Pagan (BP) (1979) and Koenker (1981) tests were used. The Koenker's test is a robust version of the BP which compensates for the sensitivity of its asymptotic power to the kurtosis of the distribution of $\varepsilon$ and delivers a more reliable asymptotic size (for a more detailed discussion, see Koenker, 1981). Therefore, when there is a conflict between these two, we rely on the Koenker test. The Koenker test indicated no presence of heteroscedasticity in the data. To check the 
autocorrelation, the Durbin-Watson test was used which revealed no autocorrelation among errors in all the regression models.

Table 1: Descriptive statistics and correlations of the variables.

\begin{tabular}{|c|c|c|c|c|c|c|c|c|c|c|c|c|c|c|c|c|}
\hline & Variables & $\mathbf{N}$ & Mean & SD & 1 & 2 & 3 & 4 & 6 & 7 & 8 & 9 & 11 & 12 & 13 & 14 \\
\hline 1. & $\mathrm{ROC}_{2001}$ & 240 & 7.91 & 10.2 & 1 & & & & & & & & & & & \\
\hline 2. & Growth 2001 & 240 & -10.4 & 653 & -.04 & 1 & & & & & & & & & & \\
\hline 4. & Research intensity 2001 & 240 & 1.35 & .636 & .04 & .01 & -.02 & 1 & & & & & & & & \\
\hline 5. & Internationalization 2001 & 240 & 16.3 & 20.7 & $.15^{*}$ & .11 & $.21^{* *}$ & -.01 & & & & & & & & \\
\hline 8. & Firm size 2014 & 147 & 48.3 & 44.8 & & & & & $.18^{*}$ & .08 & 1 & & & & & \\
\hline 9. & Research intensity 2014 & 147 & 1.90 & .963 & & & & & -.01 & -.12 & -.16 & 1 & & & & \\
\hline & Internationalization 2014 & 147 & 20.7 & 20.3 & & & & & -.14 & .09 & $.27^{* *}$ & $.27^{* *}$ & & & & \\
\hline 11. & $\mathrm{ROC}_{\text {pooled }}$ & 386 & 8.06 & 10.1 & & & & & & & & & 1 & & & \\
\hline
\end{tabular}

A quick look at the descriptive statistics reported in Table 1 shows that the size of the companies which participated in the second survey is bigger and their export share is larger. At least partly, this is indicative of the consolidation that has taken place within the industry, and that larger companies also have larger export shares. Inferring from Table 1, another interesting observation is that the overall performance of the companies and their tendencies to develop and design more innovative products increased during the period of research. Regarding the scale of internationalization, we can conclude that, on average, about $17.9 \%$ of companies' sales in the sample come from the international market, which is a high rate for SMEs. Considering Sweden as a small local market and the free trade regulations among European countries, this rate of internationalization among the investigated companies is not a surprise.

\subsection{Performance and internationalization}

Table 2 displays the results of regression analysis for ROC and internationalization in linear, quadratic, and cubic models. The results are shown separately for surveys in 2001 and 2014. The last four columns of the table pooled the results in a panel regression analysis, applying time as a dummy variable which was entered independently and as an interaction effect into the model. Following a hierarchical analysis, the control variables were entered first, then the internationalization variable, and lastly the squared and sigmoid calculations of internationalization to test the quadratic and cubic relationships.

The control variables are responsible for just .3 percent of the performance variance in 2001 ( R-square $=.003$, P>.05). This has significantly changed in 2014, when firm size and research intensity account for 10.1 percent of the total variance $(\mathrm{R}$-square $=.101, \mathrm{P}<.01)$. A closer look at the regression coefficients of size and the research intensity reveals that both are insignificant in 2001; however, the firm size is highly significant in 2014. Incorporating these results with the correlation analysis shown in Table 1 confirms size as an influential factor on the performance of the Swedish wood manufacturing industry in recent times. The conditions have changed over this time period in favor of the bigger companies. 
Adding internationalization into the analysis significantly changes the explanatory power of the model in 2001 (Rsquare change of .031, $\mathrm{P}<.01$ ), in 2014 (R-square change of .07, $\mathrm{P}<.01$ ), and in the pooled dataset (R-square change of .045, $\mathrm{P}<.01)$. The regression coefficients of $2001(\beta=-.180, \mathrm{P}<.01), 2014(\beta=-.285, \mathrm{P}<.01)$, and the pooled analysis $(\beta=-.197, \mathrm{P}<.01)$ all uncover a highly significant negative linear relationship between internationalization and performance among Swedish wood manufacturing companies. This result strongly supports the research hypothesis predicting a negative connection between internationalization and performance. As discussed before, the Swedish wood manufacturing SMEs are performing in a low research-intensive industry with a low MES point reachable through acting in the local market. Therefore, entering international markets does not seem an entirely viable strategy for them, unless they consider it as a required option to guarantee their long-term survival.

Table 2: ROC-internationalization relationship in linear, quadratic, and cubic models (hierarchical regression analysis)

\begin{tabular}{|c|c|c|c|c|c|c|c|c|c|c|c|c|}
\hline & \multicolumn{4}{|c|}{$\begin{array}{c}\text { ROC (2001) } \\
(\mathrm{N}=227)\end{array}$} & \multicolumn{4}{|c|}{$\begin{array}{c}\text { ROC (2014) } \\
(\mathbf{N}=138)\end{array}$} & \multicolumn{4}{|c|}{$\begin{array}{c}\text { ROC (pooled) } \\
(\mathbf{N}=371)\end{array}$} \\
\hline & M1 & $M 2$ & $M 3$ & M4 & $M 1$ & $M 2$ & $M 3$ & M4 & $M 1$ & $M 2$ & M3 & M4 \\
\hline Firm size & -.027 & .009 & .017 & .024 & $.298^{* *}$ & $.370^{* *}$ & $.371^{* *}$ & $.370^{* *}$ & .074 & $.147^{* *}$ & $.153^{* *}$ & $.158^{* *}$ \\
\hline Research intensity & .052 & .046 & .036 & .029 & -.072 & -.139 & -.139 & -.140 & -.034 & -.024 & -.031 & -.037 \\
\hline Internationalization & & $-.180^{* *}$ & -.316 & .016 & & $-.285^{* *}$ & -.293 & -.130 & & $-.197^{* *}$ & $-.368^{*}$ & .053 \\
\hline Internationalization $^{2}$ & & & .146 & -.818 & & & .009 & -.533 & & & .183 & -1.02 \\
\hline Internationalization $^{3}$ & & & & .679 & & & & .396 & & & & .810 \\
\hline Time & & & & & & & & & & -.086 & -.108 & -.091 \\
\hline Time* internationalization & & & & & & & & & & -.003 & .123 & -.077 \\
\hline Time* internationalization $^{2}$ & & & & & & & & & & & -.117 & .304 \\
\hline Time* $^{*}$ internationalization ${ }^{3}$ & & & & & & & & & & & & -.215 \\
\hline R-square & .003 & .034 & .038 & .045 & .101 & .171 & .171 & .173 & .007 & .052 & .055 & .063 \\
\hline Adjusted R-square & -.005 & .021 & .020 & .023 & .088 & .153 & .146 & .141 & .001 & .039 & .037 & .039 \\
\hline R-square change & .003 & .031 & .003 & .007 & .101 & .070 & .000 & .002 & .007 & .045 & .003 & .007 \\
\hline F value & .390 & $7.16^{* *}$ & .774 & 1.60 & $7.62^{* *}$ & $11.3^{* *}$ & .002 & .243 & 1.23 & $5.80^{* *}$ & .670 & 1.44 \\
\hline Breusch-Pagan test & .081 & 1.59 & 6.70 & 10.6 & 3.28 & 6.52 & 7.18 & 8.93 & 5.85 & 10.9 & $19.5^{* *}$ & $21.3^{*}$ \\
\hline Koenker test & .085 & 1.52 & 6.61 & 10.7 & 2.55 & 5.19 & 5.71 & 7.17 & 3.92 & 7.08 & 12.9 & 14.3 \\
\hline
\end{tabular}

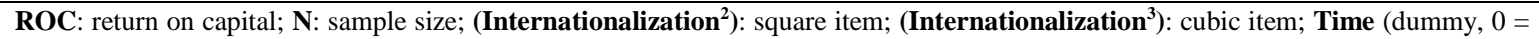
2001, 1 = 2014); M1: control model; M2: linear model; M3: quadratic model; M4: cubic model; **P<.01; *P<.05; all two-tailed tests.

As Table 1 shows, more companies are becoming interested in internationalization in 2014 compared to 2001.

Back at the beginning of this millennium, many SMEs in the wood manufacturing industry used export as a "business cycle regulator". When the economic climate was good all the focus was on the domestic market, and when the economic climate worsened the SMEs tried to export. But they did a poor job preserving international contacts and accumulating international knowledge and experience, and when the economic climate changed back export was abandoned. Therefore, in the next downturn, it was like beginning all over again. Especially after the financial crisis (in 2008-09), this behavior seems to have changed towards a more consistent export strategy. This is one explanation to why the Swedish wood manufacturing SMEs are still at the beginning of their internationalization.

The regression coefficients of square and cubic internationalization in all the models are not significant. These results suggest that the connection between the degree of internationalization and performance among Swedish wood manufacturing companies is a persistent negative linear relationship. Time in the pooled analysis and all its interactions with internationalization, square internationalization, and sigmoid internationalization are not statistically significant, indicating that the shape and direction of the internationalization-performance connection remains unchanged over time. To summarize, the shape of the internationalization-performance relationship among Swedish wood manufacturing companies is linear and the direction is negative. These results are expected, 
looking at the size and the stage of the internationalization in the whole industry. The industry is locally based and builds its core foundation on local customers' tastes. Most of the companies at the beginning of the internationalization process are facing the critical challenge of newness, which could be costly.

\subsection{Growth and internationalization}

There are a number of studies that examine the effect of internationalization on firm growth in addition to the accounting-based measures of performance to convey a deeper explanation (e.g., Lu and Beamish, 2006). In line with the intentions of these studies, we used regression analysis to test the effect of internationalization on the growth of Swedish wood manufacturing companies in 2001, in 2014, and on the pooled sample. Table 3 shows the results on the growth-internationalization relationship in the linear, quadratic, and cubic models. All the growth models were insignificant. The results clearly show that the effect of internationalization on growth is not significant.

Table 3: Growth-internationalization relationship in linear, quadratic, and cubic models (hierarchical regression analysis)

\begin{tabular}{|c|c|c|c|c|c|c|c|c|c|c|c|c|}
\hline & \multicolumn{4}{|c|}{$\begin{array}{c}\text { Growth (2001) } \\
(\mathrm{N}=222)\end{array}$} & \multicolumn{4}{|c|}{$\begin{array}{c}\text { Growth (2014) } \\
(N=135)\end{array}$} & \multicolumn{4}{|c|}{$\begin{array}{c}\text { Growth (pooled) } \\
(\mathrm{N}=\mathbf{1 6 5})\end{array}$} \\
\hline & $M 1$ & $M 2$ & $M 3$ & $M 4$ & $M 1$ & $M 2$ & $M 3$ & M4 & $M 1$ & $M 2$ & $M 3$ & $M 4$ \\
\hline Firm size & .005 & .018 & .013 & .015 & -.058 & -.057 & -.066 & -.066 & -.122 & -.128 & -.129 & -.107 \\
\hline Research intensity & -.093 & -.094 & -.089 & -.093 & .099 & .098 & .099 & .099 & -.097 & -.097 & -.106 & -.096 \\
\hline Internationalization & & -.084 & -.021 & .175 & & -.003 & .236 & .464 & & .063 & -.088 & -.044 \\
\hline Internationalization $^{2}$ & & & -.068 & -.638 & & & -.252 & -1.01 & & & .162 & .018 \\
\hline Internationalization $^{3}$ & & & & .404 & & & & .556 & & & & .100 \\
\hline Time & & & & & & & & & & .042 & .086 & .141 \\
\hline Time* internationalization & & & & & & & & & & -.065 & -.176 & -.954 \\
\hline Time* internationalization $^{2}$ & & & & & & & & & & & .100 & 2.27 \\
\hline Time* $^{*}$ internationalization ${ }^{3}$ & & & & & & & & & & & & -1.52 \\
\hline R-square & .009 & .015 & .016 & .019 & .015 & .015 & .022 & .025 & .025 & .028 & .035 & .048 \\
\hline Adjusted R-square & .000 & .002 & -.002 & -.004 & .000 & -.008 & -.008 & -.013 & .013 & -.003 & -.008 & -.008 \\
\hline R-square change & .009 & .007 & .001 & .002 & .015 & .000 & .007 & .003 & .025 & .002 & .008 & .012 \\
\hline F value & .935 & 1.51 & .168 & .511 & 1.01 & .001 & .984 & .372 & 2.10 & .131 & .614 & 1.02 \\
\hline Breusch-Pagan test & $6.33^{*}$ & 7.44 & 9.04 & 8.93 & .451 & 5.34 & 7.19 & 8.62 & 1.77 & $15.2^{*}$ & $18.7^{\text {** }}$ & $21.7^{*}$ \\
\hline Koenker test & 2.96 & 3.54 & 4.29 & 4.26 & .279 & 3.31 & 4.44 & 5.41 & 1.03 & 8.68 & 11.0 & 12.8 \\
\hline
\end{tabular}

N: sample size; $\left(\right.$ Internationalization $\left.^{2}\right)$ : square item; $\left(\right.$ Internationalization ${ }^{3}$ ): cubic item; Time $\left(\right.$ dummy, $0=2001$, 1 = 2014); M1: $^{2}$ control model; M2: linear model; M3: quadratic model; M4: cubic model; $* * \mathbf{P}<.01$; $* \mathbf{P}<. \mathbf{0 5}$; all two-tailed tests.

\subsection{Robustness test}

Although all the assumptions of regression analysis such as normality, endogeneity, heteroscedasticity, autocorrelation among errors, etc. are respected in our analysis and sometimes we were forced to remove or transform the data to meet the conditions, having a robustness test could substantially increase the reliability of the analysis. This is especially important in the case of I-P in which the current meta-analytic results revealed a significant but low (in magnitude) relationship (e.g., Bausch and Krist, 2007; Marano et al., 2016). The results of regression analysis in this study also showed a significant although low (in magnitude) negative relationship, which makes performing extra tests to ensure the robustness of the results a necessity.

The bootstrapping estimation with 1,000 resampling rounds was used to make the regression results more robust. The results of bootstrapping were perfectly in line with the regression analysis, confirming a negative linear relationship between internationalization and performance. It also confirmed the results of growth analysis showing no significant effect for internationalization on firm growth. 


\subsection{Segmented analysis}

To conduct a segmented analysis, we divided the companies into three different groups based on their degree of internationalization (DOI); domestic (no internationalization), low internationalized (DOI up to 25\%), and highly internationalized firms (DOI greater than 25\%). Then, a one-way analysis of covariance (ANCOVA) was conducted to test for the mean difference. Finally, a piecewise regression analysis was performed to examine the effect of internationalization on performance and growth among low internationalized and highly internationalized groups.

The ANCOVA analysis (Table 4) results in a significant ROC mean difference for $2001(\mathrm{~F}(2,222)=3.942, \mathrm{P}<.05)$, $2014(\mathrm{~F}(2,133)=7.162, \mathrm{P}<.01)$, and the pooled dataset $(\mathrm{F}(2,363)=6.445, \mathrm{P}<.01)$ when controlling for the company size and research intensity. A pairwise comparison reveals a significantly higher ROC for domestic companies compared to highly internationalized firms in 2001 (mean difference of $3.774, \mathrm{P}<.05$ ). However, this difference is not significant between domestic and low internationalized (mean difference of 1.695, P>.05), or low and highly internationalized companies (mean difference of 2.079, P>.05). In 2014, the ROCs of both domestic (mean difference of 6.431, $\mathrm{P}<.05$ ) and low internationalized companies (mean difference of 5.260, $\mathrm{P}<.05$ ) suppress the highly internationalized firms, and again there is no difference between domestic and low internationalized groups in terms of ROC. The same goes for the pooled dataset; a significant difference between domestic and highly internationalized (mean difference of 4.357, P<.05), low internationalized and highly internationalized (mean difference of 3.611, $\mathrm{P}<.05$ ), and no significant difference between the domestic and low internationalized companies (mean difference of .767, $\mathrm{P}<.05$ ).

Table 4: One-way ANCOVA analysis for ROC and growth of domestic, low, and highly internationalized firms

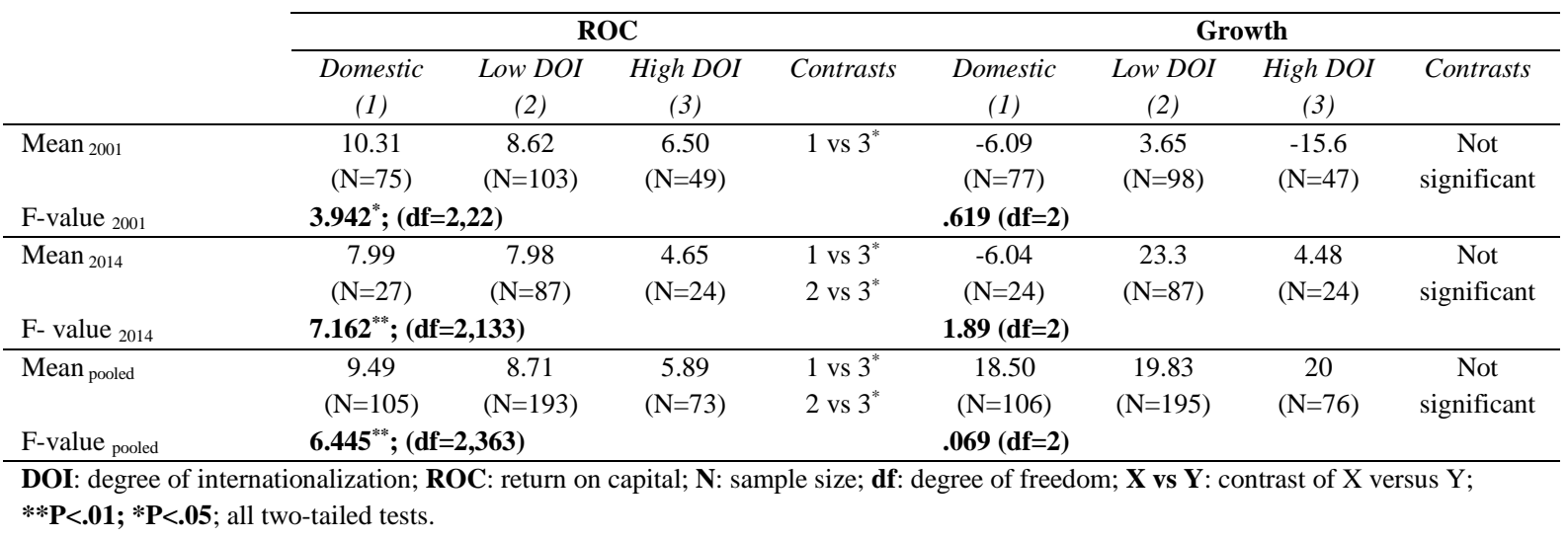

The ANCOVA analysis for growth indicates no significance difference between the domestic, low, and highly internationalized companies (Table 4, columns 4-8). These results confirm the intensive international involvement as a negative driver of performance among Swedish wood manufacturing SMEs; however, having a low level of internationalization (DOI of $25 \%$ or lower) has no significant effect. The ANCOVA analysis corroborates the regression results, demonstrating an insignificant connection between internationalization and growth.

To check how degree of internationalization behaves in each group, a piecewise regression analysis was conducted. The normality of residuals for each regression was checked with a high degree of scrutiny because of the small sample size of each split regression. Fortunately, all the residuals were normally distributed. Also, the autocorrelation among the errors was studied using the Durbin-Watson test, showing no sign of autocorrelation 
among errors. In addition, applying the BP and Koencer tests revealed no presence of heteroscedasticity and the VIF values assured us that the multicollinearity is not a challenge. For each run, a quadratic equation $\left(\right.$ Internationalization $^{2}$ ) and a cubic equation (Internationalization ${ }^{3}$ ) were tested. Table 5 shows the results for all the significant split regressions. We found three significant models of split regressions: (1) internationalizationperformance for the highly internationalized group in 2001 (I-P $\left.\mathrm{H}_{-2001}\right)$, (2) internationalization-growth for the low internationalized group in 2001(I-G M-2001), and (3) internationalization-performance for the highly

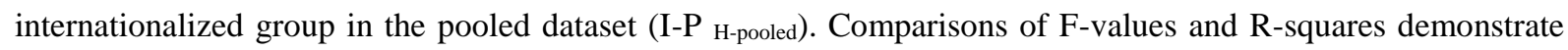
that the results generally improved when the quadratic item (Internationalization ${ }^{2}$ ) was added to the I-P $\mathrm{H}-2001$ $(\Delta \mathrm{R}=.086, \mathrm{P}<.05)$. In the cases of the $\mathrm{I}_{-} \mathrm{G}_{\mathrm{M}-2001}(\Delta \mathrm{R}=.076, \mathrm{P}<.01)$ and $\mathrm{I}-\mathrm{P}{ }_{\mathrm{H} \text {-pooled }}(\Delta \mathrm{R}=.060, \mathrm{P}<.05)$, the cubic terms are significant and add to the overall results.

Table 5: Piecewise regression analysis for ROC and growth of low and highly internationalized firms

\begin{tabular}{|c|c|c|c|c|c|c|c|c|c|c|c|c|}
\hline & \multicolumn{4}{|c|}{$\begin{array}{l}\text { ROC-high DOI (2001) } \\
\qquad(\mathrm{N}=49)\end{array}$} & \multicolumn{4}{|c|}{$\begin{array}{l}\text { Growth-medium DOI (2014) } \\
\qquad(\mathrm{N}=93)\end{array}$} & \multicolumn{4}{|c|}{$\begin{array}{c}\text { ROC-high DOI (pooled) } \\
(\mathrm{N}=74)\end{array}$} \\
\hline & $M 1$ & $M 2$ & $M 3$ & M4 & $M 1$ & $M 2$ & M3 & M4 & $M 1$ & $M 2$ & $M 3$ & M4 \\
\hline Firm size & -.134 & -.138 & -.016 & -.018 & -.047 & -.046 & -.043 & -.019 & .063 & .106 & .179 & .184 \\
\hline Research intensity & -.278 & -.289 & $-.332^{*}$ & $-.342^{*}$ & -.146 & -.147 & -.150 & -.111 & -.126 & -.059 & -.109 & -.120 \\
\hline Internationalization & & .022 & $-1.76^{*}$ & 1.16 & & -.003 & .073 & $-2.78^{*}$ & & -.218 & $-2.02^{*}$ & 5.03 \\
\hline Internationalization $^{2}$ & & & $1.81^{*}$ & -4.47 & & & -.078 & $7.07^{*}$ & & & $1.80^{*}$ & -12.9 \\
\hline Internationalization $^{3}$ & & & & 3.45 & & & & $-4.44^{* *}$ & & & & $7.83^{*}$ \\
\hline Time & & & & & & & & & & -.385 & $-2.29^{*}$ & 2.09 \\
\hline Time* internationalization & & & & & & & & & & .339 & 4.88 & 4.17 \\
\hline Time* internationalization $^{2}$ & & & & & & & & & & & -2.81 & -2.18 \\
\hline Time* $^{*}$ internationalization ${ }^{3}$ & & & & & & & & & & & & \\
\hline R-square & .087 & .087 & .173 & .186 & .024 & .024 & .025 & .101 & .019 & .057 & .134 & .194 \\
\hline Adjusted R-square & .047 & .027 & .098 & .091 & .003 & -.008 & -.020 & .049 & -.009 & -.012 & .042 & .095 \\
\hline R-square change & .087 & .000 & .086 & .012 & .024 & .000 & .000 & .076 & .019 & .038 & .077 & .060 \\
\hline F value & 2.19 & .018 & $4.58^{*}$ & .645 & 1.12 & .001 & .031 & $7.35^{* *}$ & .686 & .914 & 2.93 & $4.86^{*}$ \\
\hline Breusch-Pagan test & 1.89 & 4.75 & 2.10 & 2.71 & 3.46 & 5.72 & 5.45 & 8.53 & 1.34 & $21.6^{* *}$ & 13.9 & 15.7 \\
\hline Koenker test & 1.34 & 3.42 & 1.97 & 2.44 & 2.05 & 3.38 & 3.21 & 5.60 & .633 & 10.0 & 7.71 & 10.4 \\
\hline
\end{tabular}

For I-P $\mathrm{H}_{\mathrm{H}-2001}$, adding the square term of internationalization makes the internationalization coefficient negative ( $\beta=-1.76, \mathrm{P}<.05)$, while the quadratic term is positive $(\beta=1.81, \mathrm{P}<.05)$. This shows that the I-P relationship for highly internationalized companies in 2001 is U-shaped. In other words, increasing involvement of internationalization decreases the overall performance until the minimum point is reached. After the minimum point the I-P relationship becomes positive. Pooling both datasets from 2001 and 2014 alters the I-P relationship to an S-shaped pattern (I-P ${ }_{\text {H-pooled }}$ Model). To better show the nature of the relationships, we have graphed the results for different degrees of internationalization (Figures 1-3). 


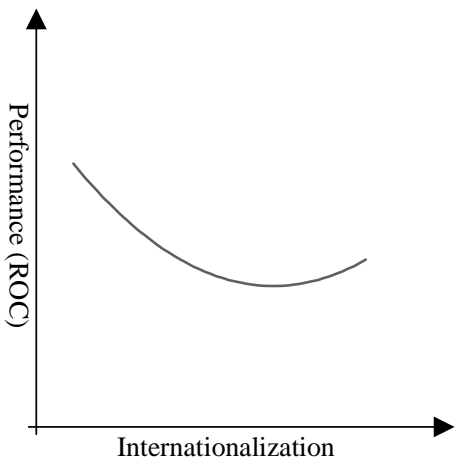

Figure 1: I-P relationship among highly internationalized companies (2001)

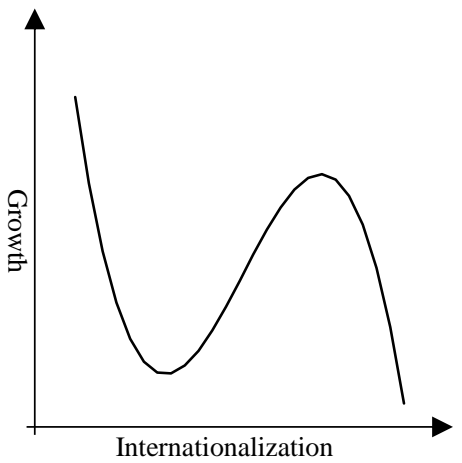

Figure 2: I-growth relationship among low internationalized companies (2001)

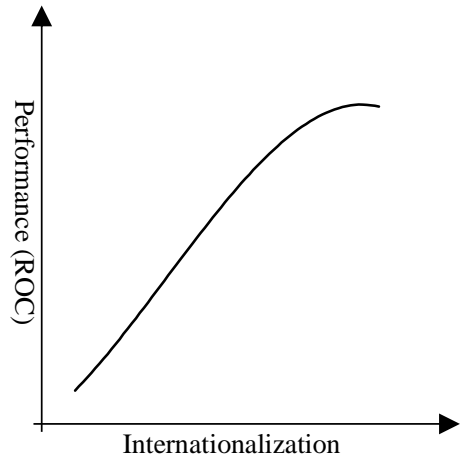

Figure 3: I-P relationship among highly internationalized companies (pooled dataset)

As Figure 1 shows, the slope is indeed negative at the beginning depicting an inverse relationship between internationalization and performance for highly international companies in 2001. As the level of internationalization becomes higher (beyond the turning point of 39-40 percent), the benefits of internationalization exceed the associated costs and thus improve the performance. These findings are in line with previous studies that demonstrated a similar inverted U-shaped relationship between internationalization and performance (e.g., Banalieva and Sarathy, 2011; Chen and Hsu, 2010; Chiao et al., 2006; Elango, 2006; Pattnaik and Elango, 2009). It is reasonable to suppose when the highly internationalized Swedish wood manufacturing companies surpass the turning point of 40 percent, their performance grows more rapidly because their investment and penetration in international markets help them to achieve higher benefits of sales opportunities. This relationship turns into a slight S-shaped pattern when the data from 2014 is added to the equation (Figure 3). In actual fact, the pooled data analysis suggests a second turning point (about 73-75 percent) which needs to be respected when studying the I-P relationship among highly international firms. All in all, the Swedish wood manufacturing companies which already earn more than $40 \%$ of their total sales from foreign markets are able to improve their performance by increasing their international engagement to $70 \%$. These findings corroborate previous studies which suggested an optimum point of internationalization somewhere between 40 and 70 percent (e.g., Ruigrok et al., 2007). Moreover, the performance consequences of internationalization for highly internationalized firms with international involvement below 39\% is negative. This is in line with the S-shape theory of internationalization in the case of highly internationalized companies (DOI of higher than 25\%) and confirms the previous studies which found an S-shaped relationship between internationalization and performance (e.g., Contractor et al., 2003; Lu and Beamish, 2004; Outreville, 2010; Ruigrok et al., 2007).

Figure 2 indicates a negative relationship between internationalization and growth for low internationalized companies in 2014 until the turning point is reached (7-8 percent). This relationship becomes positive when the companies suppress the first turning point and is continuous until the maximum point (19-20 percent). Generating more than $20 \%$ of total sales from international markets again reduces the growth of low internationalized companies. In other words, a very low involvement in international activities (less than 7 percent) decreases the overall growth of low internationalized firms in 2001. This could be due to the costs associated with the liability of newness. However, the experience and benefits gained from increasing involvement in international markets (from 7 to 20 percent) compensates for the costs of being new in these markets, and the new costs arising from managing the complexity of internationalization outweigh the benefit and reduce growth. Despite the beneficial 
effect of low international involvement (between 7-20 percent) for companies which are already involved in international markets, the maximum growth is achieved when companies focus on their domestic markets.

\section{Conclusion}

The field of international business is built upon the assumption that, other conditions being equal, involvement in a foreign market can improve performance, yet the current empirical findings on the I-P relationship are not conclusive. Researchers found significant, insignificant, positive, negative, linear, non-linear, U-shaped, inverted U-shaped, sigmoid, and inverted sigmoid relationships between internationalization and performance. Considering these inconclusive or sometimes contradictory findings, the theoretical and methodological challenges, and the disturbing effects of other factors, further studies are recommended to limit their focus on a homogeneous country, a single industry, and a specific type of company. This study limits its focus to the SMEs within the Swedish wood manufacturing industry with the aim of investigating how international activities affect the performance of those companies.

Using a pooled regression analysis backed by a bootstrapping estimation of confidence intervals, a negative relationship was found between internationalization and performance among Swedish wood manufacturing SMEs. The negative effect of international activities on performance is plausible in this case, because the whole industry is at the beginning of an internationalization phase in which more and more companies are starting to consider it as a viable strategy for their long-term survival. Most of these companies are still domestic or at the beginning of their internationalization, and suffer from what is called the "liability of foreignness and newness". The costs of internationalization are higher than the subsequent benefits in this step, and could therefore negatively affect their corporate performance. A segmented analysis using ANCOVA and piecewise regression on domestic, low, and highly internationalized companies uncovers different scenarios of I-P relationship for each segment. The I-P relationship for highly internationalized companies in 2001 follows a U-shaped pattern. This means that international involvement decreases performance until a minimum point; however, it positively affects performance afterwards. Pooling the data from 2001 and 2014 changes the relationship into an S-shaped form. In general, these findings support the benefit of internationalization for Swedish wood manufacturing companies at certain points. Therefore, we recommend that Swedish wood manufacturing companies which have already engaged in international markets should keep their foreign sales within a range in which the benefits exceed the associated costs. Furthermore, those companies that rely on the domestic market need to acquire reliable knowledge and experience before entering a new international market and should be prepared for the costs arising from the "liability of foreignness and newness".

If we look at the growth of the companies, the story is somewhat different. The effect of internationalization on the growth of Swedish wood manufacturing SMEs is generally not significant. The only significant model of growth has been that which emerged among low internationalized companies in 2001, which shows the benefit of low international involvement for companies which have already engaged in foreign markets, although they never reach the growth level of domestic firms. Considering this conclusion and the insignificant connections between internationalization and growth in 2014, in the pooled dataset, and in 2001 for highly internationalized and domestic companies, we cannot infer a firm recommendation. However, we can suggest that companies should be moderately engaged in the international market if they have chosen internationalization as a growth strategy. 
The first and major contribution of this study is the way it looks at I-P research. While the majority of the I-P studies in the literature aims at generalization by including a large number of industries or countries in their research models, this study recommends a focused investigation and limits its focus to the SMEs within the Swedish wood manufacturing industry. In fact, there is fierce discussion on the advantages of focused investigations of the relationship, which was widely ignored by previous empirical studies. Another contribution of this study is the methodological analysis. In this research, the findings of 2001 and 2014 were first compared to find what has changed over time, and then a pooled analysis was implemented to infer an overall conclusion. Also, a segmented analysis using ANCOVA and piecewise regression analysis applied to study the unique I-P relationship of different segments including domestic, low, and highly internationalized firms.

Clearly, there are some limitations in every study which could provide some suggestions for future studies. Perhaps the first limitation, which is actually an advantage of this study, is its limited focus on the Swedish wood manufacturing industry. Future studies can replicate this type of focused study in different industries and in various countries. In this way, it would be possible for future researchers to obtain a better understanding of the I-P connection in different contexts. Second, one of the controversies in the current literature regards which measure of internationalization to apply. While the discussion of using a multi-dimensional measure of internationalization is well spoken for, supplemental empirical considerations such as availability and applicable guidelines to compose different measures of internationalization are lacking, which limits the use of such measures. Future research needs to reconsider the measure of internationalization and apply more reliable measures if available. One of the major problems of the international sales to total sales ratio is that it only considers the degree of internationalization and neglects the international diversification. This should be considered in future studies. Third, this research follows a repeated cross-sectional design of longitudinal study which means taking independent samples from the same population over time. However, this type of longitudinal study is recommended for understanding the aggregate changes in a variable (Frees, 2004), and it is not as informative as pure longitudinal studies which track the same subjects over time. Future research should consider pure longitudinal analysis as a way to achieve a more informative analysis of I-P relationship.

\section{Acknowledgements}

This work was financially supported by the industry organization Swedish Wood.

\section{References}

Assaf, A.G., Josiassen, A., Ratchford, B.T., Barros, C.P., 2012. Internationalization and Performance of Retail Firms: A Bayesian Dynamic Model. Journal of Retailing 88, 191-205.

Banalieva, E.R., Sarathy, R., 2011. A Contingency Theory of Internationalization Performance for Emerging Market Multinational Enterprises. Management International Review 51, 593-634.

Barney, J., 1991. Firm Resources and Sustained Competitive Advantage. Journal of Management 17, 99-120. Bausch, A., Krist, M., 2007. The effect of context-related moderators on the internationalization-performance relationship: Evidence from meta-analysis. Management International Review 47, 319-347.

Bowerman, B.L., O'Connell, R.T., 1990. Linear Statistical Models: An Applied Approach, 2nd ed. Duxbury Press.

Breusch, T.S., Pagan, A.R., 1979. A Simple Test for Heteroscedasticity and Random Coefficient Variation. Econometrica 47, 1287-1294.

Buongiorno, J., Johnston, C., Zhu, S.S., 2017. An assessment of gains and losses from international trade in the forest sector. Forest Policy and Economics 80, 209-217. 
Chen, H., Hsu, C.W., 2010. Internationalization, resource allocation and firm performance. Industrial Marketing Management 39, 1103-1110.

Chiao, Y.C., Yang, K.P., Yu, C.M.J., 2006. Performance, internationalization, and firm-specific advantages of SMEs in a newly-industrialized economy. Small Business Economics 26, 475-492.

Contractor, F.J., 2007. Is international business good for companies? The evolutionary or multi-stage theory of internationalization vs. the transaction cost perspective. Management International Review 47, 453-475.

Contractor, F.J., Kundu, S.K., Hsu, C.C., 2003. A three-stage theory of international expansion: the link between multinationality and performance in the service sector. Journal of International Business Studies 34, 5-18.

Coviello, N.E., McAuley, A., 1999. Internationalisation and the Smaller Firm: A Review of Contemporary Empirical Research. Management International Review 39, 223-237.

Dana, L.P., Etemad, H., Wright, R.W., 1999. The Impact of Globalization on SMEs. GLOBAL FOCUS 11, 93 106.

Davis, P.S., Harveston, P.D., 2000. Internationalization and Organizational Growth: The Impact of Internet Usage and Technology Involvement Among Entrepreneur-led Family Businesses. Family Business Review 13, 107-120.

de Chernatony, L., Drury, S., Segal-Horn, S., 2005. Using triangulation to assess and identify successful services brands. The Service Industries Journal 25, 5-21.

Dess, G.G., Ireland, R.D., Hitt, M.A., 1990. Industry Effects and Strategic Management Research. Journal of Management 16, 7-27.

Elango, B., 2006. An Empirical Analysis of the Internationalization-Performance Relationship Across Emerging Market Firms. Multinational Business Review 14, 21-44.

Elango, B., Sethi, S.P., 2007. An exploration of the relationship between country of origin (COE) and the internationalization-performance paradigm. Management International Review 47, 369-392.

Fernhaber, S.A., 2013. Untangling the relationship between new venture internationalization and performance. Journal of International Entrepreneurship 11, 220-242.

Filatotchev, I., Piesse, J., 2009. R\&D, internationalization and growth of newly listed firms: European evidence. Journal of International Business Studies 40, 1260-1276.

Frees, E.W., 2004. Longitudinal and Panel Data: Analysis and Applications in the Social Sciences. Cambridge University Press.

Glaum, M., Oesterle, M.-J., 2007. 40 years of research on internationalization and firm performance: More questions than answers? Management International Review 47, 307-317.

Gold, M.S., Bentler, P.M., 2000. Treatments of Missing Data: A Monte Carlo Comparison of RBHDI, Iterative Stochastic Regression Imputation, and Expectation-Maximization. Structural Equation Modeling-a Multidisciplinary Journal 7, 319-355.

Gomes, L., Ramaswamy, K., 1999. An empirical examination of the form of the relationship between multinationality and performance. Journal of International Business Studies 30, 173-187.

Grant, R.M., 1987. Multinationality and Performance among British Manufacturing Companies. Journal of International Business Studies 18, 79-89.

Hennart, J.-F., 2000. Transaction Costs Theory and the Multinational Enterprise, in: Pitelis, C., Sugden, R. (Eds.), The Nature of the Transnational, Second Edition ed. Routledge, London, pp. 72-118.

Hennart, J.-F., 2007. The theoretical rationale for a multinationality-performance relationship. Management International Review 47, 423-452.

Hessels, J., Parker, S.C., 2013. Constraints, internationalization and growth: A cross-country analysis of European SMEs. Journal of World Business 48, 137-148.

Hitt, M.A., Tihanyi, L., Miller, T., Connelly, B., 2006. International diversification: Antecedents, outcomes, and moderators. Journal of Management 32, 831-867.

Jack, E.P., Raturi, A.S., 2006. Lessons learned from methodological triangulation in management research. Management Research News 29, 345-357.

Johanson, J., Vahlne, J.E., 1977. The Internationalization Process of the Firm: A Model of Knowledge Development and Increasing Foreign Market Commitments. Journal of International Business Studies 8, 23-32.

Kirca, A.H., Hult, G.T.M., Roth, K., Cavusgil, S.T., Perryy, M., Akdeniz, M.B., Deligonul, S., Mena, J.A., Hoppner, J.J., Miller, J.C., White, R.C., Pollitte, W.A., 2011. Firm-Specific Assets, Multinationality, and Financial Performance: A Meta-Analytic Review and Theoretical Integration. Academy of Management Journal 54, 47-72. 
Koenker, R., 1981. A Note on Studentizing a Test for Heteroscedasticity. Journal of Econometrics 17, 107-112. Kuratko, D.F., Audretsch, D.B., 2013. Clarifying the Domains of Corporate Entrepreneurship. International Entrepreneurship and Management Journal 9, 323-335.

Kylaheiko, K., Jantunen, A., Puumalainen, K., Saarenketo, S., Tuppura, A., 2011. Innovation and internationalization as growth strategies: The role of technological capabilities and appropriability. International Business Review 20, 508-520.

Laaksonen-Craig, S., 2004. Foreign direct investments in the forest sector: implications for sustainable forest management in developed and developing countries. Forest Policy and Economics 6, 359-370.

Lane, P.J., Salk, J.E., Lyles, M.A., 2001. Absorptive capacity, learning, and performance in international joint ventures. Strategic Management Journal 22, 1139-1161.

Leonidou, L.C., 2004. An Analysis of the Barriers Hindering Small Business Export Development Journal of Small Business Management 42, 279-302.

Leonidou, L.C., Katsikeas, C.S., Palihawadana, D., Spyropoulou, S., 2007. An Analytical Review of the Factors Stimulating Smaller Firms to Export. International Marketing Review 24, 735-770.

Little, R.J.A., 1988. Robust Estimation of the Mean and Covariance Matrix from Data with Missing Values. Applied Statistics 37, 23-38.

Lu, J.W., Beamish, P.W., 2001. The Internationalization and Performance of SMEs. Strategic Management Journal 22, 565-586.

Lu, J.W., Beamish, P.W., 2004. International diversification and firm performance: The S-CURVE hypothesis. Academy of Management Journal 47, 598-609.

Lu, J.W., Beamish, P.W., 2006. SME internationalization and performance: Growth vs. profitability. Journal of International Entrepreneurship 4, 27-48.

Ma, A., Norwich, B., 2007. Triangulation and Theoretical Understanding. International Journal of Social Research Methodology 10, 211-226.

Majocchi, A., Zucchella, A., 2003. Internationalization and performance - Findings from a set of Italian SMEs. International Small Business Journal 21, 249-268.

Marano, V., Arregle, J.L., Hitt, M.A., Spadafora, E., van Essen, M., 2016. Home Country Institutions and the Internationalization-Performance Relationship: A Meta-Analytic Review. Journal of Management 42, 10751110 .

McDougall, P.P., Oviatt, B.M., 1996. New venture internationalization, strategic change, and performance: A follow-up study. Journal of Business Venturing 11, 23-40.

McWilliams, A., Siegel, D., 2000. Corporate social responsibility and financial performance: correlation or misspecification? Strategic Management Journal 21, 603-609.

Nollet, J., Filis, G., Mitrokostas, E., 2016. Corporate social responsibility and financial performance: A nonlinear and disaggregated approach. Economic Modelling 52, 400-407.

Nord, T., Brege, S., 2014. En framtida hållbar trävärdekedja : Struktur, utveckling och möjligheter, LIU-IEI-R. Linköping University Electronic Press, Linköping, p. 124.

Outreville, J.F., 2010. Internationalization, Performance and Volatility: The World Largest Financial Groups. Journal of Financial Services Research 38, 115-134.

Pattnaik, C., Elango, B., 2009. The Impact of Firm Resources on the Internationalization and Performance Relationship: A Study of Indian Manufacturing Firms. Multinational Business Review 17, 69-88.

Pedhazur, E.J., 1997. Multiple Regression in Behavioral Research: Explanation and Prediction. Harcourt Brace College Publishers.

Ruigrok, W., Amann, W., Wagner, H., 2007. The internationalization-performance relationship at Swiss firms: A test of the S-shape and extreme degrees of internationalization. Management International Review 47, 349-368.

Ruigrok, W., Wagner, H., 2003. Internationalization and Performance: An Organizational Learning Perspective. MIR: Management International Review 43, 63-83.

Sharp, B.M., Bergh, D.D., Li, M., 2013. Measuring and Testing Industry Effects in Strategic Management Research: An Update, Assessment, and Demonstration. Organizational Research Methods 16, 43-66.

Sullivan, D., 1994. Measuring the Degree of Internationalization of a Firm. Journal of International Business Studies 25, 325-342.

Thomas, D.E., 2006. International diversification and firm performance in Mexican firms: A curvilinear relationship? Journal of Business Research 59, 501-507. 
Tsao, S.-M., Chen, G.-Z., 2010. The impact of internationalization on performance and innovation: The moderating effects of ownership concentration. Asia Pacific Journal of Management 29, 617-642.

Tushman, M.L., Rosenkopf, L., 1996. Executive Succession, Strategic Reorientation and Performance Growth: A Longitudinal Study in the U.S. Cement Industry. Management Science 42, 939-953.

Wan, W.P., Hoskisson, R.E., 2003. Home country environments, corporate diversification strategies, and firm performance. Academy of Management Journal 46, 27-45.

Wiersema, M.F., Bowen, H.P., 2011. The Relationship between International Diversification and Firm Performance: Why It Remains a Puzzle. Global Strategy Journal 1, 152-170.

Wynarczyk, P., Watson, R., 2005. Firm Growth and Supply Chain Partnerships: An Empirical Analysis of U.K. SME Subcontractors. Small Business Economics 24, 39-51.

Yeoh, P.L., 2004. 'International Learning: Antecedents and Performance Implications among Newly Internationalizing Companies in an Exporting Context. International Marketing Review 21, 511-535.

Zhang, X., Deng, J., Su, R., 2016. The EM algorithm for a linear regression model with application to a diabetes data, 2016 International Conference on Progress in Informatics and Computing (PIC), pp. 114-118.

Zhang, Y., Toppinen, A., 2011. Internationalization and financial performance in the global forest industry. International Forestry Review 13, 96-105.

Zhang, Y.J., Toppinen, A., Uusivuori, J., 2014. Internationalization of the forest products industry: A synthesis of literature and implications for future research. Forest Policy and Economics 38, 8-16. 